\title{
Os Estados Unidos e as negociações sobre a criação do posto de Alto Comissário para Direitos Humanos da ONU
}

\author{
The United States and the negotiations on the creation \\ of the United Nations High Commissioner for Human Rights
}

Matheus de Carvalho Hernandez ${ }^{1}$

Resumo: A literatura sobre direitos humanos normalmente credita às mobilizações das ONGs lideradas pela Anistia Internacional a aprovação consensual, em 1993, da criação do posto de Alto Comissário para Direitos Humanos da ONU, o principal responsável por direitos humanos dentro da ONU. Contudo, há outro importante ponto a ser considerado para compreender essa aprovação: a mudança de posição dos EUA em relação à pauta. Durante a Guerra Fria, os EUA eram apenas discretos apoiadores da proposta em razão da priorização dos cálculos geopolíticos do período. Terminada a Guerra Fria, a sistemática oposição da URSS à criação do posto desapareceu. Assim, a administração Clinton, que pretendia se mostrar como a principal responsável por uma mudança positiva na política externa de direitos humanos do país em comparação à antecessora $\mathrm{H}$. Bush, tornou-se a principal apoiadora da criação do posto de Alto Comissário para Direitos Humanos da ONU. O objetivo deste artigo não é negar a relevância das mobilizações das ONGs em 1993, mas apenas evidenciar como aquele contexto histórico criou as condições para que os EUA pragmaticamente assumissem a liderança da proposta.

Palavras-chave: EUA. ONU. Direitos Humanos. Alto Comissário para Direitos Humanos da ONU.

(cc) EY Direito autoral e licença de uso: Este artigo está licenciado sob uma Licença Creative Commons. Com essa licença você pode compartilhar, adaptar, para qualquer fim, desde que atribua a autoria da obra, forneça um link para a licença, e indicar se foram feitas alterações. 


\begin{abstract}
The literature on human rights usually owes to NGOs mobilizations lead by Amnesty International the consensual approval, in 1993, of the creation of the UN High Commissioner for Human Rights, the main responsible for human rights inside the UN. However, there is another important point to be considered to understand this approval: the changing of the US position regarding the issue. During the Cold War, US was just a reticent supporter of the proposal due to the prioritization of the geopolitical calculations of the period. Ended the Cold War up, the solid opposition of the USSR on the creation of the post disappeared. Thus, Clinton's administration, which intended to show itself as the responsible for a positive improvement of the US human rights foreign policy when compared to the $\mathrm{H}$. Bush, became the main sponsor of the creation of the UN High Commissioner for Human Rights. The goal of this article is not to deny the relevance of the NGOs mobilizations in 1993, but only to show that that historical context created the conditions to the US pragmatically takes the lead of the proposal.
\end{abstract}

Keywords: United States. United Nations. Human Rights. UN High Commissioner for Human Rights.

\title{
Introdução
}

Graças à articulação transnacional e pressão de ONGs de direitos humanos lideradas pela Anistia Internacional: esse é o fator preponderantemente destacado pela literatura sobre direitos humanos quanto às indagações a respeito do sucesso da aprovação da proposta de criação do posto de Alto Comissário das Nações Unidas para os Direitos Humanos (ACNUDH) em 1993. ${ }^{2}$ E certamente a mobilização de tais organizações foi indispensável para gerar um ambiente político propício à inesperada aprovação consensual do mandato de Alto Comissário. Certo também é que as mobilizações não-governamentais em 1993, ano da Segunda Conferência Mundial para os Direitos Humanos da ONU (conhecida como Conferência de Viena), foram muito mais organizadas e sistemáticas do que aquelas vistas ao longo de todas as tentativas de criação do posto durante a Guerra Fria.

Entretanto, por mais pressão que as ONGs possam ter feito, foram os representantes estatais que formularam e obtiveram o consenso ao redor do texto do mandato do ACNUDH. Portanto, a compreensão dessa aprovação em 1993 passa inevitavelmente por olhar também a posição dos Estados a respeito da pauta em 1993, em comparação aos seus posicionamentos em relação a ela desde as primeiras tentativas nos anos quarenta. Nesse sentido, a mudança de postura dos EUA, que passa de discreto apoiador da pauta durante a Guerra Fria à liderança protagonista em 1993, salta aos olhos. Identificar e compreender, portanto, a atuação dos EUA ao longo das tentativas de criação do posto até a sua aprovação após a Conferência de Viena é o objetivo deste artigo. 
O Alto Comissário é o principal responsável pelas temáticas de direitos humanos dentro da ONU e peça central nessa arquitetura institucional. Apesar disso, possivelmente em virtude de o posto e o escritório (com mais de mil funcionários) que o auxilia não serem uma arena intergovernamental propriamente dita, mas uma burocracia alocada dentro do Secretariado da ONU, recebe pouca atenção da literatura especializada. As pouco abundantes obras sobre o tema foram escritas quase todas elas por ativistas ou por funcionários da ONU imbuídos de uma pretensão prescritiva, e não analítica e histórica. Por isso, o presente artigo, cuja intenção é justamente reconstruir e analisar a participação dos EUA ao longo das negociações para a criação do posto, se vale não só de revisão bibliográfica, mas também de análise de documentos (obtidos via internet e por meio de pesquisa presencial na biblioteca da ONU em Genebra) e de uma série de mais de cinquenta entrevistas (semiestruturadas e anônimas) realizadas ao longo de 2012 e 2016 com ativistas, diplomatas de vários países e funcionários da ONU.

Tendo em vista que a participação dos EUA nesse processo praticamente nunca foi sistematizada e analisada, a discussão será concentrada nas negociações específicas a respeito do ACNUDH e em seus detalhes ao invés de se caminhar para análises mais amplas a respeito da política externa de direitos humanos dos EUA, já bastante debatida pela literatura internacional. ${ }^{3}$ Assim, o objetivo primordial do artigo é mostrar como a mudança de uma postura de discreto apoio à proposta pelos EUA, condicionados pela lógica sistêmica da Guerra Fria, à outra de protagonismo, motivada pelo fim da Guerra Fria e pela ânsia do governo Clinton de se diferenciar de seu antecessor, é fator indispensável para compreender o sucesso das negociações a respeito da criação do ACNUDH em 1993.

\section{As tentativas de criação do ACNUDH durante a Guerra Fria e a participação dos EUA}

Ao longo da segunda metade da década de quarenta, a França fez uma primeira proposta de criação de um Alto Comissário para direitos humanos no âmbito da ONU, mas ela não recebeu muita prioridade dos Estados e da recém-criada organização, naquele momento preocupados com a Declaração Universal dos Direitos Humanos e com o Pacto vinculante de direitos humanos que se pretendia seguir a ela. ${ }^{4}$

E foi no contexto de discussão a respeito do Pacto que o debate sobre a criação de um ACNUDH surgiu pela primeira vez com mais notoriedade. Durante o governo Truman, que atribuiu baixa ou nenhuma prioridade à criação do ACNUDH, os EUA, em 1951, propuseram, no âmbito da Comissão de Direitos Humanos (CDH) da ONU, a elaboração de um protocolo de petições individuais ao Pacto. O Uruguai, aproveitando o momento político, emendou a proposta dos EUA e conseguiu incluir sua proposta de um Alto Comissário 
como uma organização que zelaria pelo Pacto e teria o poder de receber petições. ${ }^{5}$

O bloco soviético, liderado pela URSS, se colocou fortemente contrário à ideia de criação de um Alto Comissário naquele momento de forte tensão da Guerra Fria. Na realidade, a resistência soviética à criação do ACNUDH viria a se tornar uma constante durante toda a Guerra Fria. Os soviéticos argumentavam que, caso criado, o posto representaria uma autoridade supranacional a respeito de questões que seriam de foro exclusivo da jurisdição doméstica dos Estados. O clima de Guerra Fria fica claro quando se observa a interpretação a respeito da frequente resistência soviética ao projeto do ACNUDH veiculada por Patrick Flood, que esteve a serviço da missão dos EUA na ONU, em Genebra, na primeira metade da década de oitenta, e foi um dos principais mobilizadores da proposta de criação do ACNUDH naquele contexto:

I believe that the real reason was that it feared that a High Commissioner, as an advocate of the values expressed in the Universal Declaration, would focus much of his or her attention on abuses in Communist states. The Soviets naturally opposed creating what they saw as a new antiSoviet pressure point. Worse, such a pressure point would speak and act in the name of the whole community of states and could thereby help frustrate Soviet efforts to project their power and influence in the Third World. ${ }^{6}$

Depois dessas primeiras e tímidas tentativas frustradas de criação de um Alto Comissário para os direitos humanos ao longo das décadas de quarenta e cinquenta, a ideia se arrefeceu um pouco dentro da estrutura da ONU na segunda metade dos anos cinquenta. Um dos motivos para os debates sobre o ACNUDH não terem ganhado prioridade na agenda da ONU nos anos cinquenta foi o fato dos EUA, seja no governo Truman, seja no governo Eisenhower, estarem direcionando seus esforços muito mais para os embates geopolíticos com a URSS e para a reconstrução europeia.

Mas na década de sessenta, o debate se reacendeu. E isso ocorreu em grande medida porque a ideia de se criar um Alto Comissário para os direitos humanos voltou a ser debatida no âmbito do Departamento de Estado dos EUA, especificamente em 1963, já durante o governo do democrata John Kennedy. Richard Gardner, então Deputy Assistant Secretary of State for International Organization Affairs (1961-1965), foi um personagem importante naquele momento. ${ }^{7}$

O estabelecimento da proposta de criação de um Alto Comissário parece ter sido desencadeado, nos EUA, por dois eventos no início de 1963. Em abril daquele ano, Marieta Tree, então delegada do país na CDH, enviou a Gardner um artigo do Manchester Guardian descrevendo o trabalho do novo 
ombudsman da Nova Zelândia junto com uma nota que assim dizia: "Can this ever be suggested for the UN? I recognize political problems here. But couldn't we talk to Senators informally to get their views?" Esse foi o primeiro impulso endógeno para a proposta de criação do ACNUDH dentro do aparato burocrático dos EUA. ${ }^{8} \mathrm{O}$ segundo e importante evento, que também ocorreu em abril de 1963, foi um convite do American Jewish Committee a Gardner para participar de um seminário. A agenda para esse encontro continha um item intitulado "High Commissioner (Attorney-General, or "Ombudsman") for Human Rights."

Até esse momento, os esforços internos de Gardner eram direcionados para que o governo Kennedy revertesse o quadro de oposição dos EUA às convenções internacionais de direitos humanos, estabelecido no governo Eisenhower. Nesse sentido, os esforços de Gardner vinham surtindo algum efeito, já que Kennedy enviou ao Senado três convenções para serem ratificadas em julho de 1963: a Convenção Suplementar contra a Escravidão, de 1956, a Convenção sobre os Direitos Políticos da Mulher, de 1952, e a Convenção sobre a Abolição do Trabalho Forçado (OIT), de 1957

Mas, a partir desse momento, Gardner juntamente com Tree começaram a direcionar seus esforços, também pela necessidade suscitada pela agenda do American Jewish Committee, para a criação de um Alto Comissário. Examinaram a proposta original e consideraram possíveis variações daquela proposta uruguaia. A exposição de Gardner no seminário tocou muito levemente nessa questão, entretanto, em julho, várias reuniões ocorreram no Departamento de Estado sobre a ideia de um Alto Comissário para direitos humanos, com a intenção de incluir tal temática no discurso de Kennedy, que viria a ser realizado na Assembleia Geral da ONU, que ocorreria em setembro daquele mesmo ano de $1963 .{ }^{9}$

A ideia foi objetada por praticamente todos os setores do Departamento de Estado. Argumentava-se que um Alto Comissário poderia embaraçar o governo dos EUA ou alguns dos regimes ditatoriais que se aliavam aos EUA. Vale lembrar que durante o conflito sistêmico com a URSS, os EUA, apesar de se colocar como um defensor e promotor internacional da democracia e dos direitos humanos, fez diversas alianças com Estados e governos não democráticos e com históricos sistemáticos de violação aos direitos humanos.

Também se argumentava que a URSS e outros governos se oporiam à proposta - o que, de fato, ocorreu - e que a defesa da proposta pelos EUA atrapalharia o desenvolvimento da détente, que estava se iniciando com a conclusão do tratado proibindo testes nucleares. Porém, a inesperada oposição veio, naquele momento, do Ministério da Justiça, chefiado por Robert Kennedy. Segundo ele, os EUA não poderiam encabeçar tal proposta antes do Civil Rights Act ser aprovado, naquele momento paralisado no Congresso. Ele temia que a criação de um Alto Comissário para direitos humanos pudesse incitar 
o aumento da oposição sulista. Por conta disso, a ideia de os EUA apoiarem de forma mais robusta a criação de um Alto Comissário aparentemente havia sido deixada de lado em $1963 .^{10}$

Por outro lado, Gardner e Tree teriam sido autorizados a discutir a criação do ACNUDH com John Humphrey, Diretor da Divisão de Direitos Humanos da ONU. Como resultado, Humphrey teria começado a disseminar a ideia dentro do Secretariado da ONU ${ }^{11}$. Ao mesmo tempo, Gardner promoveu encontros informais com vários representantes de ONGs de direitos humanos a fim de recordá-los da existência das propostas anteriores de criação do ACNUDH.

Nesse processo, Jacob Blaustein, ex-presidente do American Jewish Committee e delegado dos EUA na Assembleia Geral, depois de um discurso na Universidade de Columbia (EUA) em 1963, assumiu a proposta. Nesse discurso, Blaustein criticou a política de direitos humanos para a ONU de Kennedy e, vocalizando as críticas dos judeus-americanos ao governo do democrata, disse que assumir a liderança do projeto de criação do ACNUDH seria uma boa forma de os EUA retomarem seu papel como indutor e promotor do sistema de direitos humanos da ONU. ${ }^{12}$

O discurso de Blaustein recebeu razoável publicidade nos EUA. Gardner expressou apoio pessoal, ao contrário do restante do Departamento de Estado, à proposta publicizada por Blaustein. Humphrey citou trecho de tal discurso em sua participação no World Jewish Congress para defender a criação do posto. Um mês depois desse discurso, Blaustein foi chamado pelo Departamento de Estado para debater a questão. ${ }^{13}$

Em fevereiro de 1964, já no governo Lyndon Johnson, Humphrey enviou a Blaustein um documento elaborando a proposta de criação do Alto Comissário a ser defendida por ele em seu encontro com o Departamento de Estado. Blaustein passou a sugerir que o ACNUDH pudesse ser útil em várias áreas, usando como exemplos as crises do Chipre e do Vietnã, na tentativa de persuadir o Departamento de Estado dos EUA. ${ }^{14}$

Humphrey tinha um grande trânsito entre as ONGs que adotaram a proposta de criação do ACNUDH depois do discurso de Blaustein. Sendo assim, os dois passaram a se valer dessa rede de contatos com altos funcionários de ONGs para impulsionar a ideia de criação do ACNUDH de um modo que nenhum dos dois e suas respectivas representações institucionais (ONU e EUA) aparecessem publicamente como ponta de lança dessa proposta. Entre esses contatos estavam Peter Benenson, fundador e Secretário-Geral da Anistia Internacional, e Seán MacBride, na época Presidente da Comissão Internacional de Juristas e membro do Comitê Internacional da Anistia Internacional. Nesse momento, a discreta articulação entre Blaustein, Gardner e Humphrey em favor da construção de uma proposta de criação do ACNUDH passava a integrar a agenda de ONGs internacionais de direitos humanos. ${ }^{15} \mathrm{~A}$ partir daí, a Divisão 
de Direitos Humanos da ONU, representada por Humphrey, cogitou que os EUA pudessem introduzir a ideia no âmbito da ONU, mas isso foi rapidamente descartado pelo Departamento de Estado, tendo em vista que 1964 era ano eleitoral nos EUA e que Lyndon Johnson não estava disposto a se desgastar junto a republicanos e sulistas em nome de uma proposta sobre o sistema de direitos humanos da ONU. ${ }^{16}$

Assim, as configurações geopolíticas da Guerra Fria, o momento eleitoral nos EUA e as realidades políticas dentro da ONU exigiam que a proposta de criação de um Alto Comissário fosse encabeçada por um país não alinhado e que não gerasse reações adversas já de saída. O bloco soviético não aceitaria uma proposta com nascedouro no Departamento de Estado dos EUA e os países árabes ficariam muito reticentes com uma proposta vinda de organizações judaicas, como o American Jewish Committee. Assim, representantes da Costa Rica foram procurados por Humphrey e Gardner e aceitaram liderar o projeto de criação do ACNUDH no âmbito da CDH em $1965 .{ }^{17}$

Nesse momento, isto é, no fim de 1964 e início de 1965, o governo Lyndon Johnson, a despeito da aprovação do Civil Rights Act e do fim do período eleitoral, não estava disposto a tomar iniciativa sobre a questão de um Alto Comissário para direitos humanos da ONU. Apesar disso, Gardner (1972) conseguiu que Morris Abram, então representante dos EUA na CDH, recebesse autorização para apoiar um estudo sobre a proposta de criação de um Alto Comissário no âmbito daquela Comissão, em março de 1965. ${ }^{18}$

No âmbito dos fóruns de direitos humanos da ONU nos quais a Costa Rica tentou introduzir a pauta, com discreto apoio dos EUA, encontrou resistência soviética, que argumentava que questões de soberania estavam envolvidas e que interferências nas questões internas dos Estados soberanos deveriam, na visão soviética, ser evitadas. Assim, as tensões políticas envolvidas no debate impediram que qualquer resolução fosse emitida. ${ }^{19}$

No âmbito da Assembleia Geral, em setembro, em seu primeiro discurso, o embaixador dos EUA Arthur Goldberg expressou publicamente apoio à proposta de criação do ACNUDH. ${ }^{20}$ Com tal apoio, a Costa Rica solicitou que o item fosse considerado por um Grupo de Trabalho (GT) da Assembleia, o que não ocorreu. ${ }^{21}$ Assim, posso dizer que a proposta da Costa Rica passou longe de conseguir ser votada e, mais ainda, de ser aprovada em 1965, mesmo com o apoio dos EUA. Possivelmente, inclusive, o apoio público dos EUA naquele momento pode ter contribuído para levantar ainda mais resistências ao projeto de criação de um posto de Alto Comissário de direitos humanos.

Membros do bloco árabe e do bloco soviético eram as principais resistências. Fundamentavam sua posição com a acusação de que os princípios que embasavam a proposta eram carregados de uma "ocidentalidade" potencialmente benéfica às potências ocidentais, destacadamente os EUA. A condição estrutural e estruturante da Guerra Fria como tônica do sistema 
internacional naquele momento, portanto, é absolutamente indispensável para compreender porque todos os movimentos dos EUA em relação à proposta mesmo apoios discretos e de bastidores - tinham inevitáveis consequências para o andamento das negociações e, em especial, levantavam a resistência dos soviéticos em relação a ela. ${ }^{22}$

AURSS se posicionou invariavelmente contra a proposta do ACNUDH, a despeito do fato de os EUA não exercerem o tempo todo papel de liderança em relação a ela (ainda que fossem simpáticos ao projeto). Durante esse debate de 1966, por exemplo, o representante soviético sugeriu que o apoio dos EUA à proposta de criação era uma forma de tentar convencer a opinião mundial de que o país tinha ativa participação na causa dos direitos humanos, quando, na realidade, eles nem mesmo haviam ratificado as Convenções da ONU que envolviam questões de direitos humanos. ${ }^{23}$

Segundo uma experiente ativista do Jacob Blaustein Institute entrevistada, dentro do Departamento de Estado dos EUA, havia um desejo de fazer algo no campo dos direitos humanos, mas tal desejo convivia com um receio de tomar qualquer ação específica. Tal receio decorria de uma variedade de causas, inclusive de que as inações dos EUA em matéria das convenções internacionais de direitos humanos fossem criticadas internacionalmente e receio da ascensão de crítica interna, advinda especialmente de republicanos e sulistas. Como resultado, nenhum direcionamento político claro emergiu por parte dos EUA em relação à pauta, diferente do que ocorreu em 1993, como poderá ser visto na seção seguinte.

Como dito acima, possivelmente a mera aproximação ou a mera identificação dos EUA com a pauta tenha contribuído para que ela não caminhasse. O nome de Blaustein, um ex-presidente do American Jewish Committee e delegado dos EUA na Assembleia Geral, vinculado à pauta de criação do ACNUDH certamente não contribuiu para aglutinar apoiadores. A condução realizada pela Costa Rica também não contribuiu para desatrelar os EUA da proposta de criação do posto de Alto Comissário, pois reforçava o protagonismo de Blaustein ao, por exemplo, citá-lo explicitamente em memorandos, afastando os países árabes. ${ }^{24}$

Foi esse panorama dos posicionamentos políticos que levou, a despeito da mobilização em torno da proposta, à postergação da decisão acerca da criação no âmbito da Assembleia Geral da ONU no fim dos anos sessenta e início dos anos setenta. ${ }^{25}$ Por conta disso, apesar de alguns debates terem ainda permanecido na Subcomissão de Prevenção da Discriminação e Proteção das Minorias e na Comissão de Direitos Humanos da ONU, a pauta foi perdendo destaque político na agenda da organização no final dos anos sessenta e primeira metade dos anos setenta, especialmente pela priorização da détente no governo Nixon e da ascensão da Realpolitik de Kissinger, cujo êxito poderia ser atrapalhado por mais uma pauta de dimensão moral que colocava EUA e 
URSS em lados opostos e conflitantes, como era o caso da proposta de criação do ACNUDH. ${ }^{26}$

A baixa prioridade atribuída aos temas de direitos humanos por Nixon (e Kissinger) e a instabilidade política do governo de Gerald Ford, que assumiu a presidência em 1974 após o conturbado escândalo de Watergate, contribuíram decisivamente para que a proposta de criação do ACNUDH quase desaparecesse do radar do Departamento de Estado e, com isso, perdesse força no seio da ONU. ${ }^{27}$ Em 1975, por exemplo, a criação de um Alto Comissário nem mesmo entrou na pauta da Assembleia Geral. Aparentemente, o projeto havia declinado sem muitas chances de voltar à agenda da ONU.

Porém, não foi isso que ocorreu. A pauta voltou a ser discutida na CDH já em 1977, tendo os EUA sob a presidência de Jimmy Carter, o qual elevou notoriamente a importância dos direitos humanos na agenda da política externa dos EUA. ${ }^{28}$

A major factor of that time was the active human rights policy of US President Jimmy Carter. The Carter administration had put human rights prominently on the international political agenda. It must be assumed that it was not by coincidence that already in the first year of the Carter presidency the proposal of the High Commissioner was relaunched. The United States was not a co-sponsor of the draft resolution but gave its support to it in the person of the United States UN Ambassador Andrew Young (BOVEN, 2007: p. 771. Grifo meu). ${ }^{29}$

Naquele ano, depois de quase uma década, o projeto de criação de um Alto Comissário para os direitos humanos saiu novamente da $\mathrm{CDH}$ e encaminhou-se à Assembleia Geral por força de uma articulação liderada pela Costa Rica e pela Suécia, com apoio dos EUA. Porém, uma vez mais, o avanço da pauta foi obstaculizado pela associação entre a resistência soviética à proposta, de um lado, e, de outro, a reticência dos EUA em assumir o protagonismo da propositura, mesmo durante o governo Carter. Os soviéticos afirmavam que o Procedimento 1503 da Comissão de Direitos Humanos (que envolvia a Comissão em debates confidenciais a respeito de violações) e a análise dos relatórios dos Estados-parte pelo Comitê do Pacto de Direitos Civis e Políticos já eram suficientes e que a criação de um Alto Comissário representaria uma intromissão nas soberanias estatais. ${ }^{30}$ Além disso, em 1977, a maioria dos membros da ONU eram ex-colônias. E, segundo Flood (se apoiando em uma conversa informal que ele teria tido com Bertrand Ramcharan ${ }^{31}$ ) e um experiente ex-funcionário da ONU entrevistado, os soviéticos teriam argumentado junto aos países recém-independentes que um Alto Comissário seria uma proposta neocolonialista. Com isso, conseguiram aliados entre os 
líderes do Movimento Não Alinhado (Índia, Argélia e Iugoslávia) e Cuba. Tudo isso, a despeito de alguma incipiente pressão da Anistia Internacional (muito menor quando comparada à pressão de 1993), obrigou que costa-riquenhos e suecos retirassem a proposta a fim de que ela não fosse derrotada no voto ou emendada de maneira deturpadora pelos seus não apoiadores. ${ }^{32}$

No começo da década de oitenta, uma nova tentativa de criação do posto de Alto Comissário foi inicialmente capitaneada por Itália, Costa Rica e Senegal. É importante ressaltar que há poucas referências na literatura a essa proposta da década de oitenta, tornando a análise documental e as entrevistas ainda mais imprescindíveis para a reconstrução histórica a que se propõe esta seção. ${ }^{33}$

Uma das poucas obras, juntamente com Lord ${ }^{34}$, a dedicar espaço às propostas de criação de um Alto Comissário nos anos oitenta é de autoria de Patrick Flood ${ }^{35}$. Flood, porém, não é um acadêmico propriamente dito, mas um diplomata. Na primeira metade da década de oitenta, Flood esteve a serviço da missão dos EUA na ONU, em Genebra. Flood foi um dos principais mobilizadores da proposta de criação do cargo de Alto Comissário naquele contexto. Em janeiro de 1981, ainda sob a administração Carter, Flood enviou o seguinte telegrama ao Departamento de Estado dos EUA, às vésperas da sessão anual da $\mathrm{CDH}$ :

The session provides an opportunity to achieve significant advances in the multilateralization of efforts to implement universal human rights standards. Success in this institutionbuilding effort would assure more even-handed and lesspoliticized treatment of human rights issues in the UN [...] Establishment of the post of High Commissioner would bring greater impartiality, coordination, and year-round continuity to UN human rights activities. We believe the terms of reference for a High Commissioner should strike a balance between independence and power of initiative to engage in direct contacts, on the one hand, and periodic policy supervision of activities by an "intergovernmental oversight committee" (which could be the Human Rights Commission itself) [...] A balanced approach of the type just described could command sufficient support. ${ }^{36}$

O que Flood conseguiu foi novamente apenas o apoio do Departamento de Estado, mas não o compromisso de que os EUA assumiriam a liderança da proposta. Sem força política, uma vez mais a proposta nem foi colocada em votação em 1981. Em razão da percepção de que a Comissão estaria pressionada a debater a pauta no ano seguinte, o próprio Flood desenvolveu uma proposta e a submeteu ao Departamento de Estado dos EUA, em dezembro de 1981, logo após o fechamento da Assembleia Geral, e recebeu autorização para circulá-la 
entre as missões em Genebra dos dez Estados membros ocidentais da Comissão de Direitos Humanos da ONU. ${ }^{37}$ Apesar dessa autorização, vale lembrar que nesse momento Flood já não respondia mais à administração Carter, mas à administração Reagan, cujo foco na agenda internacional de direitos humanos era muito menor quando comparado a seu antecessor. ${ }^{38}$

Ao circular esse projeto dos EUA informalmente ao longo de 1982, a maioria das delegações ocidentais foram favoráveis. Mas uma espécie de renovação da Guerra Fria vivenciada na década de oitenta durante o governo Reagan estimulou ainda mais a resistência do bloco soviético em relação à criação do posto de Alto Comissário. ${ }^{39}$

Nesse momento, a questão entre as delegações ocidentais era decidir se elas estariam dispostas a despender tempo, energia e capital político-diplomático em nome da aprovação de uma proposta ambiciosa e não consensual como aquela. A decisão, naquele momento, foi negativa, especialmente porque o governo Reagan estava concentrando seus esforços na condenação aos abusos de direitos humanos na Polônia, onde dois meses antes uma lei marcial havia sido imposta frente ao contexto de mobilização do movimento Solidariedade. ${ }^{40}$

De 1983 a 1985, a presença dos EUA nas tentativas de criação do posto deveu-se muito mais ao esforço de Flood e de sua equipe do que a uma deliberação advinda do Departamento de Estado. ${ }^{41} \mathrm{Na}$ realidade, nesse momento, como em diversos outros durante a Guerra Fria, a mobilização dos EUA em relação à pauta foi derivada muito mais de esforços individuais de alguns diplomatas e burocratas ou muito setoriais dentro do Departamento de Estado do que de um posicionamento robusto do governo dos EUA, o qual, em diferentes administrações, emprestou apoio, mas não liderança à criação do ACNUDH.

Flood afirma que, durante seu mandato, teve que despender grande quantidade de energia para tentar convencer o Departamento de Estado e, especialmente, o governo Reagan a manter o apoio dos EUA em relação ao projeto de criação do posto de Alto Comissário. ${ }^{42}$ Sendo assim, em 1985, por uma série de mudanças de cargo, inclusive o fim do mandato de Flood, houve pouca pressão para que a Comissão de Direitos Humanos da ONU discutisse a criação do posto, fazendo com que ela caísse em relativo esquecimento nos anos seguintes.

O governo Reagan tinha resistência em apoiar a criação do cargo de Alto Comissário de direitos humanos e, de fato, pude perceber, a partir das entrevistas com antigos funcionários da ONU e experientes ativistas, que o apoio dos EUA estava longe de ter o peso político que poderia ter caso houvesse convicção por parte da administração Reagan e de seus antecessores, mesmo Carter. Seja por desinteresse em si ou por foco em outras questões atinentes à Guerra Fria (como os acontecimentos no leste europeu e as disputas com a URSS), o governo Reagan, como os presidentes que o precederam, não assumiu 
o protagonismo na condução da pauta de criação do ACNUDH em virtude de cálculos geopolíticos e domésticos.

Contudo, por outro lado, é observável que os EUA votaram favoravelmente à criação do posto durante todas as tentativas dos anos quarenta aos anos oitenta. Isso ganhou importância dentro do processo das negociações quando, em 1993, os EUA, já sob a administração Clinton, não só encamparam e capitanearam a proposta de criação do ACNUDH, mas também trouxeram consigo o capital político de terem sido históricos defensores da proposta.

\section{A criação do ACNUDH em 1993 e a participação dos EUA}

Foi justamente com o fim da Guerra Fria que o tema dos direitos humanos ganhou nova força na agenda internacional. O fim do embate direto entre EUA e URSS, com a prevalência das potências ocidentais capitalistas e seus preceitos, trouxe um suposto otimismo ao cenário internacional. Essa expectativa, fundamentada no projeto de disseminação dos direitos humanos, da democracia e do desenvolvimento, estimulou a convocação, para 1993, da Segunda Conferência Mundial para os Direitos Humanos, a chamada Conferência de Viena. ${ }^{43}$

Nesse momento, abriu-se uma janela de oportunidade para que a criação do posto de ACNUDH voltasse a ser debatida. O então Secretário-Geral da Anistia Internacional, Pierre Sané, chegou a visitar diferentes países na época, como França e EUA, para avivar o interesse ocidental pela Conferência, de modo geral, e para "lembrá-los" da pauta do ACNUDH, de modo específico. Uma coalizão de ONGs dos EUA também reivindicou a criação do posto durante o processo preparatório da Conferência. ${ }^{44}$

Apesar de toda essa importante mobilização que, de fato, representou uma inflexão no ambiente preparatório da Conferência, a pauta em si do ACNUDH só foi abertamente discutida na quarta e última sessão preparatória do evento. ${ }^{45}$ Mais do que uma questão de espaço na agenda, segundo os vários diplomatas que entrevistei e que fizeram parte dessas sessões preparatórias, havia uma percepção generalizada entre os negociadores de que a pauta do ACNUDH, tendo em vista sua envergadura política e institucional, atrapalharia a construção do frágil consenso que ali se elaborava. Segundo um diplomata mexicano, havia negociações privadas e confidenciais entre algumas delegações-chave e, mesmo nesses pequenos grupos, a questão da criação do ACNUDH não era debatida, pois praticamente todos ali acreditavam que essa discussão colocaria em risco a formação de consensos.

Daí emerge o fator indispensável para compreender como a pauta do ACNUDH chegou ao processo preparatório e à Conferência em si: o fato de os EUA terem assumido não só um posicionamento favorável à criação (o que historicamente sempre fizeram), mas, de forma inédita, terem dado a ela um status de prioridade política em Viena. Tendo em vista o seu poder singular 
no sistema internacional, ainda mais nesse momento de imediato pós-Guerra Fria, os EUA tornaram-se um Estado decisivo nessas negociações, ou seja, a aprovação da pauta dependia da aceitação pelos norte-americanos não apenas porque eles representavam um voto (como qualquer outro país na ONU), mas porque eram e são dotados de estruturas de poder estratégicas e normativas com alta capacidade para aglutinar outras delegações ao redor de seus posicionamentos. ${ }^{46}$ Não havendo mais a necessidade de incluir nos cálculos e nos custos políticos a sistemática resistência soviética, os EUA passam a liderar a proposta em Viena. ${ }^{47}$

Compreender tal mudança, além da questão do fim da Guerra Fria, passa por levar em conta que Clinton elevou a importância dos direitos humanos na sua plataforma de campanha para se diferenciar de seu antecessor, George H. Bush, altamente criticado por sua indiferença em relação ao tema, especialmente por não tê-lo levantado em suas relações com a China. ${ }^{48}$ (APODACA, 2006; MERTUS, 2005). Uma vez eleito, Clinton nomeou algumas pessoas com forte ligação com os direitos humanos: Warren Christopher (discursante e chefe da delegação dos EUA na Conferência de Viena), que chefiava o Inter-Agency Group on Human Rights and Foreign Assistance durante o governo Carter, foi nomeado Secretário de Estado; e John Shattuck (participante ativo na Conferência de Viena), na época diretor da ONG American Civil Liberties Union (ACLU) e vice-presidente da Anistia Internacional, foi nomeado chefe do recém-renomeado Bureau of Democracy, Human Rights, and Labor. Clinton também preencheu o segundo escalão com várias pessoas reconhecidamente defensoras de direitos humanos. Com isso, o Departamento de Estado se abriu mais à pauta de criação do ACNUDH e à participação (e pressão) das ONGs de direitos humanos. ${ }^{49}$

Registrar essa abertura é muito importante, pois o apoio dos EUA à criação do ACNUDH e a mobilização de ONGs em prol da pauta não são fatores isolados. Tanto na literatura sobre a Conferência de Viena quanto na literatura menos abundante sobre o ACNUDH não se explica de onde veio esse apoio norte-americano à pauta. A documentação da Conferência também não revela tal processo. Por isso, só consegui rastrear panoramicamente o processo por meio de entrevistas. Um diplomata dos EUA e um diplomata polonês, este último um ativo participante em Viena, afirmaram em entrevista que, além da importância geral da mobilização das ONGs, a articulação realizada por uma ONG específica, o Jacob Blaustein Institute (JBI), foi um fator de grande importância para que a gestão Clinton assumisse a pauta do ACNUDH. E isso ocorreu às vésperas da última reunião do Comitê Preparatório da Conferência de Viena, entre abril e maio de 1993.

Vale lembrar, conforme mencionado na seção anterior, que o influente judeu-americano Jacob Blaustein havia realizado em 1963 na Universidade Columbia um discurso pró-ACNUDH. Por isso, o instituto que nasceu em sua 
homenagem tem ligação histórica com essa pauta específica. ${ }^{50} \mathrm{O} \mathrm{JBI}$ estava envolvido na mobilização liderada pela Anistia Internacional e presente nos debates das ONGs sobre o ACNUDH. Por isso, o JBI, sediado nos EUA, enviou uma representante à $\mathrm{ONU}$ no período que antecedia a realização daquela quarta sessão preparatória.

Essa representante, a qual tive a oportunidade de entrevistar em Genebra em 2014, começou a tentar convencer delegados de várias nacionalidades a respeito da pertinência da pauta do ACNUDH, mas a maioria deles achava muito improvável que se discutisse essa questão em Viena, tendo em vista que havia outras pautas complexas em debate, como a universalidade. A exceção foi um delegado polonês, chamado Zdzislaw Kedzia (atualmente membro do Comitê de Direitos Econômicos, Sociais e Culturais), que viria a ser, juntamente com o canadense Ross Hynes e o brasileiro Gilberto Sabóia, personagens importantes nas negociações a respeito do ACNUDH da Assembleia Geral de 1993, âmbito no qual o posto foi finalmente aprovado.

Até aquele momento, a delegação dos EUA não tinha expressado nenhum apoio declarado representativo à criação do ACNUDH. Apesar disso, segundo o diplomata norte-americano mencionado acima e essa ativista-chave do JBI, a gestão Clinton, recém-eleita, estava à procura de algo politicamente representativo no campo dos direitos humanos de modo a se diferenciar da postura de H. Bush..$^{51}$ Diante dessa janela política, o JBI sugeriu à John Shattuck que tal guinada fosse a liderança dos EUA no projeto de criação do ACNUDH.

Inicialmente, a reação de Shattuck, até pouco tempo um ativista da ACLU e da Anistia Internacional, foi reticente. Segundo ele, a gestão H. Bush, no período de transição, os havia aconselhado a não se envolver com a pauta do ACNUDH, pois um posto de alta importância política como esse poderia gerar constrangimentos aos EUA em matéria de direitos humanos. Por isso, a delegação dos EUA resistia um pouco a assumir publicamente a defesa da proposta. Isso teria começado a mudar quando o JBI e algumas outras ONGs, às vésperas da quarta sessão preparatória da Conferência, estavam em atividade de lobby junto a um assistente de Shattuck na sede da ONU em Genebra. Diante dessa atividade, esse assistente pediu ao JBI que redigisse então um memorando explicando quais seriam os argumentos pertinentes para a criação do ACNUDH, qual deveria ser sua posição institucional dentro da ONU e, o mais importante, por quais razões a administração Clinton deveria apoiar tal pauta. Esse memorando - que incluiu entre seus argumentos o fato da proposta gozar do apoio dos países latino-americanos e do novidadeiro apoio da Rússia e de grande parte dos países do ex-bloco soviético - parece ter sido decisivo para convencer Shattuck e, assim, para que os EUA assumissem a pauta do ACNUDH na última sessão preparatória da Conferência ${ }^{52}$. Uma importante ativista norte-americana de direitos humanos, que se mobilizou pela criação 
do ACNUDH, me disse o seguinte a respeito da participação dos EUA na pauta em Viena:

[...] eles assumiram a proposta e queriam vê-la no esboço do documento preparatório da Conferência. Embora eles não estivessem entusiasmados a respeito das chances de aprovação da proposta na Conferência, eles não se opuseram e passaram a apoiá-la na administração Clinton. E eles realmente se mobilizaram pela proposta em Viena e expressaram apoio publicamente.

Obviamente, é muito difícil afirmar com convicção que exista uma relação direta de causalidade entre o lobby do JBI e o fato de os EUA terem assumido a pauta do ACNUDH naquele momento, e tampouco é essa a pretensão aqui. Menos pretensioso do que isso, o objetivo aqui é tentar jogar luz em um fator que possa compor a explicação de um fenômeno absolutamente importante para a compreensão da aprovação do ACNUDH, mas jamais bem explicado pela literatura. $\mathrm{O}$ fato é que, apesar de pouco explicado pela literatura, a administração Clinton submeteu um conjunto de recomendações durante justamente a quarta e última sessão preparatória da Conferência. Mais do que simplesmente um conjunto de recomendações, os EUA submeteram um esboço de um plano de ação para a Conferência. E a primeira e destacada preocupação do documento era o estabelecimento do ACNUDH. ${ }^{53}$

Portanto, é esse processo de negociação política e de articulação entre ONGs e o Departamento de Estado dos EUA que está por detrás deste pronunciamento de Christopher já no Plenário da Conferência:

Today, on behalf of the United States, I officially present to the world community an ambitious action plan that represents our commitment to pursue human rights, regardless of the outcome of this Conference. This plan will build on the UN's capacity to practice preventive diplomacy, safeguard human rights, and assist fledgling democracies. We seek to strengthen the UN Human Rights Center and its advisory and rapporteurial functions. We support the establishment of a UN High Commissioner for Human Rights. ${ }^{54}$

Com os EUA na dianteira da defesa da criação do ACNUDH, a Declaração e Programa de Ação de Viena, documento final da Conferência, recomendou que a sessão seguinte da Assembleia Geral, ainda em 1993, concedesse alta prioridade aos debates sobre a criação do posto. ${ }^{55}$ Nesse momento, o debate sairia dos salões da ONU em Genebra, cidade que concentra 
os mecanismos e fóruns sobre direitos humanos, e passaria à Nova York, centro de poder da organização e palco da Assembleia Geral.

A partir daí, somente um grupo muito restrito de ativistas pôde acompanhar de perto o desenrolar dos debates intergovernamentais. Esse pequeno grupo, pelo que pude investigar pelas entrevistas, foi formado por Andrew Clapham, da Anistia Internacional, Mike Posner, da Lawyers Committee, Kenneth Roth, da Human Rights Watch, Felice Gaer, do Jacob Blaustein Institute e um representante da International Human Rights Law Group.

É muito importante mencionar que todas essas ONGs, exceto a Anistia, são sediadas nos EUA, o que facilitou que elas fizessem lobby junto ao governo norte-americano. Esse grupo se reuniu algumas vezes, por exemplo, com John Shattuck e Timothy Wirth, à época Under Secretary of State for Global Affairs do Departamento de Estado. Nessas conversas, ambos disseram aos ativistas que o governo Clinton gostaria de ver a proposta do ACNUDH aprovada e que pressionaria para tal na Assembleia Geral vindoura.

Shattuck afirmou em uma publicação logo após a Conferência de Viena: "This fall we will press forward in New York at the U.N. General Assembly on the action plan we submitted at Vienna. We will seek the establishment of a U.N. High Commissioner on Human Rights [...]". ${ }^{56}$ Segundo uma ex-ativista da International Commission of Jurist (atualmente funcionária do escritório do ACNUDH), "[...] o que as ONGs norte-americanas fizeram foi convencer a administração Clinton de que ela precisava basicamente mostrar que ela era multilateral. [...] Assim, a administração Clinton prestou apoio à ideia e isso foi chave para terminar tendo aprovada a proposta do ACNUDH.”. Clinton, vale salientar, chegou a enviar um documento à Assembleia Geral em setembro de 1993 no qual afirmou: "Today I call on this General Assembly to create, at long last, a High Commissioner for Human Rights." ${ }^{57}$

Em virtude da pressão aberta dos EUA, já no primeiro encontro o presidente do Terceiro Comitê da Assembleia Geral, o embaixador eslovaco Eduard Kukan, expôs sua proposta de que os debates sobre o ACNUDH fossem restritos a um grupo de trabalho informal (GT). Os países ocidentais se manifestaram rapidamente e em bloco de modo favorável à proposta, o que causou desconfiança entre as outras delegações. Depois desse anúncio do presidente do Terceiro Comitê, sessenta e uma delegações se pronunciaram. ${ }^{58}$ Desses pronunciamentos, pode-se depreender a existência de dois grandes grupos: aqueles países que pretendiam debater somente a questão do ACNUDH, basicamente formado pelos países ocidentais desenvolvidos e liderados pelos EUA; e um segundo e numeroso grupo formado por países favoráveis, como o Brasil, a que se desse início às discussões sobre a criação do ACNUDH em conjunto com outros itens relevantes da Declaração e Programa de Ação de Viena. O embate se referia, portanto, a se o mandato 
do GT se restringiria apenas ao ACNUDH ou a outros encaminhamentos de Viena.

Diante dos dissensos e, segundo um embaixador brasileiro entrevistado, da relutância dos EUA em ceder, o presidente do Comitê resolveu convidar um aglomerado de países para a realização de consultas informais: Austrália, Bélgica, Brasil, Canadá, Chile, Egito, Equador, EUA, Gâmbia, Holanda, Iêmen, Indonésia, Malásia, México, Singapura, Síria e Suécia. Os EUA, apoiados pelo Canadá, muito relutantemente aceitaram a realização dessas consultas, pois não estavam dispostos a admitir a abertura do mandato do GT a outras pautas. Segundo um diplomata norte-americano entrevistado, a relutância dos EUA devia-se ao temor de a abertura do GT a outras pautas constituir-se em uma estratégia para não se debater sobre o ACNUDH.

Dessa forma, o GT foi formado e chefiado pelo Representante Permanente do Equador na ONU, embaixador José Ayala Lasso, que posteriormente viria a ser o primeiro Alto Comissário para os Direitos Humanos da ONU. ${ }^{59}$

Os europeus ocidentais argumentavam em favor de uma rápida aprovação pelo GT do mandato do ACNUDH, o qual deveria, na visão desses atores, ser um posto extremamente independente..$^{60}$ Os EUA, apoiados por Canadá e Austrália, focavam primordialmente a agenda do ACNUDH nos direitos civis e políticos. ${ }^{61}$ Os latino-americanos, com exceção de Cuba, e a maioria dos africanos defendiam a criação do ACNUDH, mas ressaltavam sempre a importância dos direitos econômicos, sociais e culturais e do direito ao desenvolvimento. ${ }^{62}$ Os asiáticos e africanos mais próximos das proposições do Movimento Não Alinhado, além de Cuba, contestavam a pertinência da criação do ACNUDH e argumentavam que o consenso só seria obtido se a ideia de condicionar as ajudas para o desenvolvimento às situações de direitos humanos fosse retirada do mandato do ACNUDH, o que, de fato, aconteceu. ${ }^{63}$

Os países do leste europeu e a Rússia, as grandes novidades do polo apoiador do ACNUDH no pós-Guerra Fria, ressaltavam a necessidade de o ACNUDH responder rapidamente diante de crises. ${ }^{64}$ Essa posição não está desvinculada do contexto conflituoso do leste europeu naquele momento e na expectativa, vivida por aqueles países, de se reinserirem no "mundo ocidental".

Na penúltima reunião de novembro, data limite para a apresentação de resoluções no Terceiro Comitê, a delegação de Cuba apresentou uma resolução que postergava a discussão para o ano seguinte (prática recorrente durante a Guerra Fria, conforme visto na seção anterior). A alegação de Cuba era de que não havia um esboço formal sobre o qual se pudesse debater.

Terminada a fala do delegado cubano, a delegação dos EUA tomou a mais incisiva ação para a criação do ACNUDH desde os debates dos anos quarenta. Para surpresa de praticamente toda a audiência, a delegação norteamericana formalizou unilateralmente a apresentação de um esboço do mandato do ACNUDH, com uma estrutura para a seleção e operação do ACNUDH 
anexada.${ }^{65}$ Segundo Clapham, "The effect of this decision was electric. Coming as it did one minute before the deadline for tabling normal resolutions in the Third Committee, it came as a complete surprise and offended a number of delegations." "66. Se o GT não completasse seu trabalho sobre o ACNUDH até o final de 1993, o Terceiro Comitê da Assembleia Geral seria obrigada a apresentar para a votação a resolução proposta unilateralmente pelos EUA. Entretanto, segundo Clapham, não se sabia se a proposta dos norte-americanos seria aceita ou não na votação. ${ }^{67}$

Essa apresentação unilateral dos EUA gerou muito descontentamento entre várias delegações. Segundo um diplomata brasileiro entrevistado, Madeleine Albright, à época chefe da missão dos EUA, foi pessoalmente à reunião seguinte do GT explicar a atitude de sua delegação. Ela afirmou que, diante da proximidade da data limite para submissão de projetos de resolução no âmbito do Terceiro Comitê da Assembleia Geral e da incerteza acerca das possibilidades de postergação desse prazo, a iniciativa tinha como objetivo permitir a existência de um projeto dos EUA sobre a mesa. Ela também alegou à audiência do GT que, enquanto uma maioria representativa havia explicitado apoio à pauta, um número de delegações influentes (provavelmente se referindo ao Movimento Não Alinhado) permanecia questionando a necessidade de criação do cargo ${ }^{68} \mathrm{O}$ temor de Albright e da administração Clinton era de que essas delegações pudessem retardar o desenvolvimento das negociações ou até mesmo bloquear o consenso. Apesar disso, Albright ressaltou como aquele esboço tinha sido concebido de forma atenta aos debates que vinham ocorrendo dentro do GT e que, por isso, caso Ayala Lasso obtivesse êxito em seu trabalho de construção de consenso, os EUA poderiam retirar imediatamente seu projeto.

A despeito desse esclarecimento de Albright, a maioria das delegações do GT expressou manifesta preferência por trabalhar com o esboço de Ayala Lasso, e não dos EUA, ou seja, a pressão exercida pelos EUA acabou, de um lado, aumentando a legitimidade de Ayala Lasso junto às delegações, e, de outro, tornando praticamente indisponível ao GT a opção de não redigir o esboço do mandato do ACNUDH. Na verdade, tanto o diplomata brasileiro quanto o diplomata polonês entrevistados afirmaram que um pequeno grupo de redação, no qual eles estavam incluídos, já conhecia anteriormente a proposta dos EUA, mas não tinha clareza de quando (e se) eles a apresentariam, tal como fizeram. ${ }^{69}$

A situação política criada pela ação inesperada e unilateral dos EUA permitiu que as negociações fossem retomadas tendo como base o projeto apresentado por Ayala Lasso. Mas em reação à ação dos EUA, a Malásia, uma das lideranças do Movimento Não Alinhado, apresentou uma proposta com emendas ao projeto norte-americano. As emendas malaias removiam a estrutura estabelecida pelos EUA e a substituíam por um texto semelhante aos pontos elaborados pela proposição original do Movimento Não Alinhado, cujos elementos principais responsabilizavam o ACNUDH pela promoção de 
cooperação internacional em direitos humanos e direito ao desenvolvimento (ressaltando a necessidade de eliminar condicionalidades internacionais para a promoção de tal direito) e reivindicavam que o respeito à soberania, à integridade territorial e à jurisdição doméstica dos Estados fossem importantes princípios norteadores do ACNUDH. ${ }^{70}$

Entretanto, as outras delegações e o próprio GT, que trabalhava justamente em cima da elaboração de uma resolução consensual que fomentasse um mandato também consensual do ACNUDH, ficaram novamente desconfortáveis com a ação da Malásia, tal como tinham reagido à iniciativa dos EUA. ${ }^{71}$ Diante do impasse e do clima político desfavorável, os representantes de Malásia e EUA terminaram por retirar (não oficialmente) suas propostas de discussão e esperaram que a atividade do GT findasse. ${ }^{72}$

Conforme dito acima, as proposições unilaterais - de EUA e Malásia aproximaram as delegações de Ayala Lasso, aumentando seu prestígio junto a elas. Com isso, as negociações ao redor do mandato do ACNUDH começaram a caminhar dentro do GT. Entretanto, dois pontos ainda atravancavam o fechamento de uma formulação consensual: a questão da vinculação das ajudas ao desenvolvimento às situações de direitos humanos dos países (muito destacada por um ex-funcionário da Anistia, atualmente membro do International Commission of Jurists, que tive a oportunidade de entrevistar) e o - polêmico desde Viena - direito ao desenvolvimento.

O grupo ocidental, liderado pelos EUA, se opunha a qualquer formulação que retirasse as condicionalidades. ${ }^{73}$ As delegações do Movimento Não Alinhado e do G-77, por sua vez, transformaram a derrubada das condicionalidades em sua bandeira durante as negociações. ${ }^{74}$ A delegação dos EUA também se opôs à referência ao direito ao desenvolvimento, do qual os EUA, que não assinaram a Declaração sobre o Direito ao Desenvolvimento (UN, 1986), são os mais tradicionais opositores do sistema internacional. ${ }^{75}$

Após longas e intensas negociações, Ayala Lasso foi capaz de encontrar formulações acomodatícias que conseguiram atender às várias posições em disputa no GT. Ele, por exemplo, retirou a menção à dispensa das condicionalidades, atendendo aos EUA (e deixando a questão sem definição clara), mas incluiu o direito ao desenvolvimento, contemplando os países em desenvolvimento, de forma geral, e o Movimento Não Alinhado, de forma específica. $^{76}$

Assim, depois dessa polarizada negociação, o GT conseguiu aprovar, em 11 de dezembro, por consenso, uma proposta de mandato do ACNUDH a ser submetida ao Terceiro Comitê em 13 de dezembro, âmbito no qual também foi aprovada sem votos contrários. ${ }^{77}$ Depois da aprovação no Terceiro Comitê, a proposta finalmente chegou à Assembleia Geral, algo raras vezes conseguido durante a Guerra Fria. Legitimada pelo complexo consenso construído no GT e no Terceiro Comitê, depois de quase cinquenta anos desde a primeira tentativa 
de criação, a resolução, que teve os EUA como principal defensor, foi aprovada consensualmente pela Assembleia Geral da ONU, em 20 de dezembro de $1993 .{ }^{78}$

\section{Considerações finais}

O objetivo deste artigo foi evidenciar, de forma pormenorizada, a importância da participação dos EUA na criação do ACNUDH. Conforme dito desde o início deste trabalho, é comum que a literatura sobre direitos humanos e sobre o ACNUDH credite a aprovação da proposta em 1993 à mobilização realizada pelas ONGs internacionais de direitos humanos sob a liderança da Anistia Internacional. Entretanto, negligencia-se um fator muito importante: a mudança de posicionamento dos EUA em relação às tentativas anteriores.

Durante a Guerra Fria, os EUA emprestaram um apoio discreto à pauta, condicionado estruturalmente pela prioridade concedida aos cálculos geopolíticos do conflito bipolar. O fim da Guerra Fria representou, assim, uma conjunção entre o fim da sistemática resistência soviética à pauta e o anseio do governo Clinton se apresentar, logo no início do seu mandato, como uma mudança positiva em relação a seu antecessor em matéria de direitos humanos.

Esse anseio de Clinton de contrastar com o governo de $\mathrm{H}$. Bush tornou o governo dos EUA momentaneamente mais aberto à pressão das ONGs que se mobilizavam pela criação do ACNUDH em 1993. Portanto, este artigo não nega ou subestima a importância das ONGs, mas apenas mostra que o momento histórico no qual se inseriu o governo Clinton gerou as condições de oportunidade para que os EUA assumissem pragmaticamente a liderança do projeto de criação do ACNUDH.

Essa postura, entretanto, não significa de modo algum que a política externa do governo Clinton tenha sido plenamente comprometida com direitos humanos. A análise, por exemplo, do posicionamento da política externa em direitos humanos para a China perante a análise da política externa em geral em relação à China demonstra que, a despeito da retórica e de um real impulso inicial favorável ao tema, os direitos humanos permaneceram submetidos a outros interesses no governo Clinton.

Clinton havia criticado especialmente o fato de seu antecessor não ter retirado o status de Nação Mais Favorecida da China depois da ocorrência do Massacre da Praça da Paz Celestial, apesar de depois o próprio Clinton ter mantido o status chinês, contradizendo o discurso proferido em Viena, sob a mesma alegação de necessidade de engajamento a partir do comércio para fomentar direitos humanos. Durante a campanha e mesmo no início do governo, Clinton destacou a centralidade que os direitos humanos teriam em sua política externa, inclusive advertindo diretamente a China sobre tal posição. Tal postura apareceu diversas vezes em Viena principalmente no posicionamento universalista dos EUA frente o relativismo chinês. Por outro lado, Clinton, passado o início de seu mandato, deu continuidade à política de 
seu antecessor em relação à China: manteve e expandiu as relações econômicas e comerciais entre os dois países, a despeito do histórico de violações, frustrando as expectativas iniciais dos defensores de direitos humanos.

O governo Clinton, como todos os outros governos dos EUA, se valeu, em matéria de direitos humanos, de uma abordagem pragmática, avaliando caso a caso seu posicionamento. No momento, a criação do ACNUDH foi pragmaticamente bem avaliada pelo governo Clinton. E essa é a contribuição deste artigo: evidenciar tal momento singular (em comparação com as outras tentativas durante a Guerra Fria) sem o qual dificilmente obter-se-ia uma aprovação consensual do mandato do ACNUDH, mesmo com o ambiente criado pela Conferência de Viena e pela articulação das ONGs.

É bom frisar que a liderança dos EUA na aprovação do mandato do ACNUDH acarreta e incita até hoje acusações, advindas dos países em desenvolvimento, de viés na agenda da instituição em favor dos norteamericanos. Por outro lado, é importante também esclarecer que, especialmente após a saída de Ayala Lassa do posto em 1997, os EUA foram diversas vezes criticados publicamente em função de violações de direitos humanos pelas lideranças do posto, como, por exemplo, fizeram as Alta Comissárias Mary Robinson (1997-2002), Louise Arbour (2004-2008) e Navi Pillay (2008-2014). Tanto o exame da agenda do ACNUDH quanto das tensões mantidas entre ele e os EUA fomentam perguntas interessantes a nortear novos estudos sobre a relação entre os EUA e o ACNUDH.

\section{Notas}

1 Professor de Relações Internacionais da Universidade Federal da Grande Dourados. Doutor em Ciência Política pela Unicamp. Autor da tese "O Alto Comissário das Nações Unidas para os Direitos Humanos e seu Escritório: criação e desenvolvimento institucional”, que recebeu menção honrosa no Concurso de Teses 2016 da ANPOCS. Pesquisador do Instituto Nacional de Ciência e Tecnologia para Estudos sobre os Estados Unidos (INCT-INEU). e-mail: matheushernandez@ufgd.edu.br

2 ALSTON, Philip. Neither fish nor fowl: the quest to define the role of the UN High Commissioner for Human Rights. European Journal of International Law, v. 2, 1997, p. 321-335, p. 324. BOVEN, Theo Van. The United Nations High Commissioner for Human Rights: the history of a contested project. Leiden Journal of International Law, v, 20, n. 4, 2007, p. 767-784, p. 775. CERNA, Christina. A small step forward for human rights: the creation of the post of United Nations High Commissioner for Human Rights. The American University Journal of International Law and Policy, v. 4, n. 10, 1995, p. 1265-1274, p. 1268. CLAPHAM, Andrew. Creating the High Commissioner for Human Rights: the outside story. European Journal of International Law, v. 5, 1994, p. 556-568, p. 558. COOK, Helena. The role of the High Commissioner for Human Rights: one step forward or two steps back? Proceedings of the Annual Meeting (American Society of International Law), v. 89, 1995, p. 235-242, p. 236. GAER, Felice. BROECKER, Christen L. (Eds.). The United Nations High Commissioner for Human Rights: conscience for the world. Leiden: Martinus Nijhoff Publishers, 2014, p. 4. KOREY, William. The "Diplomatic Approach" vs. the "Human Rights Approach": The High 
Commissioner for Human Rights, and the Blaustein Institute. In: KOREY, William. NGOs and the Universal Declaration of Human Rights: a curious grapevine. NY: Palgrave, 2001, p. 369-395, p. 370. LORD, Janet. The United Nations Human Rights Commissioner for Human Rights: challenges and opportunities. Loyola of Los Angeles International and Comparative Law Review, v. 17, 1995, p. 329-363, p. 351. Possivelmente, juntamente com a obra de Gaer e Broecker citada acima, a análise mais sistemática e completa feita a respeito do ACNUDH é HERNANDEZ, Matheus de Carvalho. O Alto Comissário das Nações Unidas para os Direitos Humanos e seu Escritório: criação e desenvolvimento institucional (1994-2014). Tese de Doutorado. Programa de Pós-Graduação em Ciência Política. Unicamp. 2015. 483f.

3 Alguns dos bons exemplos nesse sentido são: FORSYTHE, David. (Ed.). Human rights and comparative foreign policy. Tokyo: United Nations University Press, 2000. APODACA, Claire; STOHL, Michael. United States human rights foreign policy and foreign assistance. International Studies Quarterly, v. 43, 1999, p. 126-210. MERTUS, J. Bait and Switch: human rights and U.S. foreign policy. Nova York: Routledge, 2004. APODACA, Claire. Understanding U.S. Human Rights Policy: a paradoxical legacy. New York: Routledge, 2006. FORSYTHE, David. US foreign policy and human rights: situating Obama. Human Rights Quarterly, v. 33, n. 3, 2011, p. 767-789. LIANG-FENTON, Debra (ed.). Implementing U.S. human rights policy. United States Institute of Peace: Washington, DC, 2004.

4 UNITED NATIONS. A High Commissioner for Human Rights' Project. Commission on Human Rights. E/CN.4/AC.4/1, 1947. Inicialmente, a intenção da ONU era elaborar um pacto de direitos humanos vinculante, isto é, um tratado gerador de obrigatoriedade jurídica junto aos Estados logo após a aprovação da Declaração Universal dos Direitos Humanos em 1948. Entretanto, em razão do conflito bipolar da Guerra Fria, não foi possível elaborar um único pacto unificado. Enquanto os EUA consideravam direitos humanos apenas como direitos civis e políticos, o bloco soviético inclinava-se aos chamados direitos econômicos, sociais e culturais como expressão dos direitos humanos. Em virtude desse conflito de "gerações" de direitos humanos, foi impossível elaborar um único pacto. A solução encontrada posteriormente foi elaborar dois tratados separados, um referente aos direitos civis e políticos e outro referente aos direitos econômicos, sociais e culturais. Ambos datam de 1966, mas só entraram em vigência dez anos depois, em 1976, quando atingiram o número mínimo de ratificações.

5 Idem, A High Commissioner for Human Rights'Project. Commission on Human Rights. E/ GN.4/549, 1951a. Idem, A High Commissioner for Human Rights' Project. Commission on Human Rights. E/CN.4/606, 1951 b.

6 FLOOD, Patrick. The effectiveness of UN human rights institutions. Washington: Praeger, 1998, p. 119-120.

7 GARDNER, Richard. Preface. In CLARK, Roger Stenson. A United Nations High Commissioner for Human Rights. Hague: Martinus Nijhoff Publishers, 1972, p. xii.

8 Ibid., p. xiii.

9 CLARK, Roger Stenson. A United Nations High Commissioner for Human Rights. Hague: Martinus Nijhoff Publishers, 1972, p. 41.

10 GARDNER, Richard. Preface...Op. cit. p. xii.

11 Para uma versão ligeiramente diferente a respeito dos papeis de Gardner e Humphrey, ver: HOBBINS, A. J. Humphrey and the High Commissioner: the Genesis of the Office of the UN High Commissioner for Human Rights. Journal of the History of International Law, v. 3, 2001, p. 38-74, p. 42. 
12 Jacob Blaustein era um industrial e ex-presidente do American Jewish Committee (AJC). Blaustein havia servido como um dos consultores não governamentais da delegação dos EUA na Conferência fundadora da ONU, em São Francisco, em 1945. A proposta de Blaustein era que o Alto Comissário fosse responsável pela investigação de violações de direitos humanos, pela assistência no desenvolvimento de instituições nacionais de direitos humanos e pela consultoria em direitos humanos junto aos órgãos intergovernamentais da ONU. COLUMBIA Daily Spectator, Volume CVIII, Number 47, 5 December 1963 - Blaustein Suggests U.N. Commissioner for Human Rights, 1963. BLAUSTEIN, Jacob. Human rights: a challenge to the United Nations and to our generation. 23 - Dag Hammarskjold Memorial Lecture, Columbia University, 4 December, 1963.

13 HOBBINS, A. J. Humphrey and the High Commissioner...Op. cit. p. 43.

14 Ibid., p. 44.

15 Ibid., p. 52.

16 GARDNER, Richard. Preface...Op. cit. p. xii.

17 HOBBINS, A. J. Humphrey and the High Commissioner...Op. cit. p. 57.

18 GARDNER, Richard. Preface...Op. cit. p. xiv. O estudo, intitulado Secretary-General's Analytical and Technical Study, requisitado pela Comissão de Direitos Humanos e esperado pelo GT, foi divulgado somente em 30 de dezembro de 1966. O documento, elaborado por Egon Schwelb (ex-Vice Diretor da Divisão de Direitos Humanos e professor na Yale Law School), sintetizou comentários de várias delegações, discutiu possíveis interpretações do esboço da resolução de criação do ACNUDH, realizou surveys sobre o sistema de direitos humanos já estabelecido e estimou as implicações financeiras da criação do cargo naqueles moldes. Ver: UNITED NATIONS. Secretary-General's Analytical and Technical Study on High Commissioner for Human Rights. General Secretary. E/CN.4/AC.21/L.1, 1966 e.

19 LORD, Janet. The United Nations Human Rights Commissioner...Op. cit. p. 333.

20 GOLDBERG, Arthur. A society for all men. Vital Speeches of the Day, 11/1/65, v. 32, Issue 2, p. 34, 1965. Disponível em: <http://connection.ebscohost.com/c/speeches/9868207/ society-all-men>. Acesso em 09 ago 2015.

21 UNITED NATIONS. Resolution on High Commissioner for Human Rights' Study. General Assembly. Res. 2062, 1965 b.

22 MERTUS, J. Bait and Switch...Op. cit., p. xiv.

23 UNITED NATIONS. Report On the Twenty-Second Session. 8 March 5 April 1966. Economic and Social Council. Official Records: Forty-First Session. Supplement No. 8. Commission on Human Rights. E/4184, E/CN.4/916, 1966c.

24 HUMPHREY, John. Human rights and the United Nations: a great adventure. NY: Transnational Publishers, 1984, p. 298. Além dessa questão do protagonismo que os representantes da Costa Rica creditavam a Blaustein e, com isso, atrelavam a imagem da proposta aos EUA, outro empecilho foi a atuação de MacBride, da Comissão Internacional de Juristas, que também reivindicava o protagonismo da proposta. Não poderia haver uma forma mais eficaz de assustar os países do leste europeu em relação à proposta do que criar a impressão de que o projeto era de autoria de uma ONG da Europa ocidental como a Comissão Internacional de Juristas. Para mais detalhes, ver: HOBBINS, A. J. (Ed.). On the Edge of Greatness: The Diaries of John Peters Humphrey, First Director of the UN Division of Human Rights. Montreal: McGill University Libraries, 2000. 
25 ALSTON, Philip. Neither fish nor fowl...Op. cit. p. 323. Segundo Alston (1997), tanto as propostas da década de cinquenta quando as da década de sessenta se caracterizam pela pressão de ONGs, apoiadas por alguns governos, no sentido do surgimento de um posto que promovesse o respeito pelos Pactos de Direitos Civis e Políticos e de Direitos Econômicos, Sociais e Culturais. Tendo a discordar dessa posição de Alston, pois, especialmente na década de cinquenta, os principais argumentos para a criação do ACNUDH tinham muito mais relação com o surgimento de um posto que recebesse e denunciasse violações do que com a ideia de um guardião dos pactos propriamente ditos. Além disso, vale sempre lembrar que a ideia original da ONU, concebida no momento da elaboração da Declaração Universal, era a confecção de um pacto unificado que abrangesse todo o rol dos direitos humanos e não dois pactos separados, o que acabou ocorrendo em virtude das disputas da Guerra Fria.

26 APODACA, Claire. Understanding U.S. Human Rights Policy...Op. cit. p. 31.

27 Ibid. ver capítulo 2.

28 MERTUS, J. Bait and Switch...Op. cit., p. 27. O ano de 1977 é realmente um ano importante para a ascensão dos direitos humanos na agenda global. Além da posse de Carter, que elevou a importância da pauta na política externa dos EUA, a Anistia Internacional recebeu o Nobel da Paz no ano de 1977 em razão de sua atuação na área de direitos humanos.

29 BOVEN, Theo Van. The United Nations High Commissioner for Human Rights... Op. cit. p. 771 .

30 Ibid., p. 772.

31 Bertrand Ramcharan era, naquele momento, assistente da Divisão de Direitos Humanos da ONU e esteve presente na Assembleia Geral de 1977. Ramcharan foi Deputy High Commissioner durante a gestão de Sérgio Vieira de Mello como Alto Comissário, em 2002 e 2003, e assumiu interinamente o posto depois da morte do brasileiro, ficando no cargo até 2004, quando a canadense Louise Arbour foi indicada como Alta Comissária.

32 FLOOD, Patrick. The effectiveness of UN human rights institutions...Op cit., p. 119-120.

33 A maioria dos livros e artigos que tentam recuperar as tentativas de criação do posto de Alto Comissário para Direitos Humanos antes do fim da Guerra Fria o fazem em grande medida apoiados na tese de Clark, defendida em 1972. Por isso, costumeiramente nem mesmo mencionam as discussões a respeito da pauta ocorridas na década de oitenta. Creio ser importante salientar também que, ao final da década de sessenta e início de setenta, quando Clark escrevia sua tese, os direitos humanos ainda eram muito pouco institucionalizados no âmbito da ONU. Não havia comitês de tratados, a Convenção sobre a Discriminação Racial e os Pactos de 1966 estavam aguardando assinaturas, às petições não era dado prosseguimento, os mecanismos de relatores especiais por "temas" e "países" tampouco existiam e a Divisão de Direitos Humanos do Secretariado da ONU ainda era muito pequena.

34 LORD, Janet. The United Nations Human Rights Commissioner...Op. cit., p. 342.

35 FLOOD, Patrick. The effectiveness of UN human rights institutions... Op cit. Ver capítulo 8 .

36 UNITED STATES OF AMERICA. U.S. Mission Geneva telegram 108, Jan. 6, 1981a.

37 Idem, Telegram 12615, Jan. 6, 1981c.

38 APODACA, Claire. Understanding U.S. Human Rights Policy...Op. cit. Ver capítulo 4.

39 UNITED NATIONS. Thirty-eighth session - Summary Record of the $16^{\text {th }}$ Meeting. Commission on Human Rights. E/CN.4/1982/SR.16, 1982b, p. 4. A ata dessa reunião da Comissão 
traz um forte pronunciamento de discordância em relação à criação do posto por parte do representante da URSS: "The efficiency of the existing organs should obviously be strengthened and perfected, but it should not be forgotten that the immediate, direct observance of human rights fell within the prerogative of States themselves and their internal competence. The creation of a supranational organ such as a United Nations High Commissioner for Human Rights was therefore unacceptable and unlawful, since the West would make use of it, as a propaganda instrument of the United Nations, to intervene in the internal affairs of States under the pretext of protecting human rights. That would poison the international climate. The idea of creating a post of High Commissioner for Human Rights had been advanced for the first time in 1947 by the World Jewish Congress; many States had opposed it at that time. The idea had been taken up again in the late 1940s, with the declared intention of creating a mechanism for the implementation of the human rights Covenants, which had not yet been drafted. Today, those Covenants existed, and there was a mechanism for their implementation. The idea of a High Commissioner's Office, which was already old, could in fact prove harmful to international co-operation, and it failed to take account of the positive experience which the United Nations had gained. Remarkable results had indeed been achieved since the establishment of the United Nations, especially in the field of human rights. The Organization had brought about the liquidation of colonies and had then tackled racism and apartheid. It so happened that those who had proposed the creation of a post of High Commissioner were the very ones who criticized the United Nations and took no account of its achievements". Outros pronunciamentos do bloco soviético se seguiram nesse sentido. A representante búlgara, por exemplo, elencou uma série de justificativas para a discordância de sua delegação em relação à criação do cargo. Ver: UNITED NATIONS. Thirty-eighth session - Summary Record of the $15^{\text {th }}$ Meeting. Commission on Human Rights. E/CN.4/1982/SR.15, 1982a, p. 9-10.

40 FLOOD, Patrick. The effectiveness of UN human rights institutions... Op cit., p. 121.

41 Ver: UNITED NATIONS. Informe del Grupo de Trabajo abierto establecido de conformidad con la resolución 1982/40 de la Comisión de Derechos Humanos. Commission on Human Rights. E/CN.4/1983/64, 1983a. UNITED STATES. U.S. Mission Geneva telegram 2594, Mar. 15, 1983a. UNITED STATES. U.S. Mission Geneva telegram 3133, Mar. 25, 1983b. UNITED STATES. U.S. Mission Geneva telegram 8505, Sept. 15, 1983 c.

42 Depois da sessão da Subcomissão em 1982, Flood enviou a seguinte mensagem ao Departamento de Estado dos EUA: "If the Project is approved it will significantly improve the way the UN does business on human rights issues by adding a capacity for prompt action in urgent situations, particularly through vigorous quiet diplomacy. We urge the Department to give it high priority in our pre-Commission consultations with Western and selected Third World colleagues.” Ver: UNITED STATES. U.S Mission Geneva telegram 9832, Sept. 30, 1982b. Apesar desse apelo de Flood, o Departamento de Estado não atribuiu alta prioridade à pauta. Por isso, Flood foi obrigado a promover um lobby antes da sessão da Comissão de Direitos Humanos sem grande respaldo governamental junto a outras missões diplomáticas presentes em Genebra. Ver: FLOOD, Patrick. The effectiveness of UN human rights institutions... Op cit., p. 122.

43 Sobre a Conferência de Viena: ALSTON, Philip. The UN's human rights record: from San Francisco to Vienna and beyond. Human Rights Quarterly, vol. 16, n 2, 1994, p. 375 390. ALVES, José Augusto Lindgren. Relações internacionais e temas sociais: a década das conferências. Brasília: IBRI, 2001. BOYLE, Kevin. Stock-taking on human rights: The World Conference on Human Rights, Vienna 1993. Political Studies, n 43, 1995, p. 79-95. TRINDADE, Antônio Augusto Cançado. O processo preparatório da Conferencia Mundial de Direitos Humanos: Viena, 1993. Revista Brasileira de Política Internacional, vol. 36, $\mathrm{n}^{\circ}$ 1, 1993, p. 1-45. TRINDADE, Antônio Augusto Cançado. Balanço dos resultados da 
Conferência Mundial para os Direitos Humanos: Viena, 1993. Revista IIDH, vol. 18, 1993b, p. 11-28. TRINDADE, Antônio Augusto Cançado. Tratado de direito internacional dos direitos humanos. Vol. I., Porto Alegre: S. A. Fabris, 1997. CERNA, Christina M. Universality of human rights and cultural diversity: implementation of human rights in different socio-cultural contexts. Human Rights Quarterly, vol. 16, n. 4, 1994, p. 740-752. CHEN, Martha Alter. Engendering World Conferences: the International Women's Movement and the UN. In: GORDENKER, Leon; WEISS, Thomas G. (eds.). NGOs, the UN, and global governance. Boulder: Lynne Rienner, 1996, p. 139-155. NOVAK, Manfred. World Conference on Human Rights. Vienna: Manz, 1994. SABÓIA, Gilberto Vergne. Um improvável consenso: a Conferência Mundial de Direitos Humanos e o Brasil. Política Externa, vol.2, n.3, 1993, p. 17-38. HERNANDEZ, Matheus de Carvalho. A ascensão do tema dos direitos humanos no pós-Guerra Fria: a Conferência de Viena (1993). Mediações, v. 15, n. 1, 2010, p. 54-73. HERNANDEZ, Matheus de Carvalho. Direitos humanos e política externa norteamericana: a participação dos EUA na Conferência de Viena (1993). Brazilian Journal of International Relations, v. 2, n. 2, 2013, p. 329-351. HERNANDEZ, Matheus de Carvalho. A Conferência de Viena e a internacionalização dos direitos humanos. Curitiba: Ed. Juruá, 2014a. HERNANDEZ, Matheus de Carvalho. The rise of human rights issue in the postCold War World: the Vienna Conference (1993). Human Rights Age Journal, v. 2, 2014b, p. 86-108.

44 UNITED NATIONS. Contribution from NGO Coalition. A/CONF.157/PC/81. 1993.

45 LORD, Janet. The United Nations Human Rights Commissioner for Human Rights...Op. cit., p. 353.

46 Nesse sentido, os EUA seriam, para usar os termos de Keck e Sikkink, um Estado crítico. Ver: KECK M, SIKKINK, K. Activists beyond borders: advocacy networks in international politics. Ithaca, NY: Cornell Univ. Press, 1998.

47 HERNANDEZ, Matheus de Carvalho. Direitos humanos e política externa norte-americana...Op. cit., p. 344.

48 APODACA, Claire. Understanding U.S. Human Rights Policy...Op. cit. Ver capítulos 5 e 6. MERTUS, J. Bait and Switch...Op. cit. Ver capítulo 2.

49 HERNANDEZ, Matheus de Carvalho. Direitos humanos e política externa norte-americana...Op. cit., p. 337. Ver também NEIER, Aryeh. Watching rights. The Nation, v. 258, n. 3, January 1994, p. 79. Neier, fundador e ex-diretor executivo da Human Rights Watch, se entusiasmou naquele momento com as indicações de Clinton, as quais, segundo ele, despertaram a esperança de que os direitos humanos teriam peso e prioridade na política externa dos EUA, o que não veio a se efetivar posteriormente.

50 Nas palavras do atual diretor executivo do JBI: “[...] the Jacob Blaustein Institute for the Advancement of Human Rights (JBI) [...] has been at the vanguard of efforts to strengthen human rights protection through the creation and strengthening of effective international institutions. Since JBI's inception, one of its primary concerns has been establishing and advancing successful human rights leadership by a High Commissioner for Human Rights." Ver GOODKIND, E. Robert. Preface. In GAER, Felice D.; BROECKER, Christen L. (Eds.). The United Nations High Commissioner for Human Rights: conscience for the world. Leiden: Martinus Nijhoff Publishers, 2014, p. IX.

51 APODACA, Claire. Understanding U.S. Human Rights Policy...Op. cit.

52 Não consegui obter esse memorando, mas dois ativistas e o diplomata norte-americano entrevistados mencionaram a existência desse memorando. 
53 UNITED NATIONS GENERAL ASSEMBLY. Summary Record of the 41st Meeting. A/C.3/48/SR.41, 1993.

54 CHRISTOPHER, Warren. Democracy and Human Rights: Where America Stands. 1993, p. 5. Disponível em: $<$ http://dosfan.lib.uic.edu/ERC/briefing/dossec/1993/9306/930614dossec.html $>$. Acesso em 19 set 2011.

55 UNITED NATIONS. Vienna Declaration and Programme of Action. A/CONF.157/23. 1993. Artigo 18: "The World Conference on Human Rights recommends to the General Assembly that when examining the report of the Conference at its forty-eighth session, it begin, as a matter of priority, consideration of the question of the establishment of a High Commissioner for Human Rights for the promotion and protection of all human rights."

56 SHATTUCK, J. Vienna and Beyond: U.S. Human Rights Diplomacy in the Post-Cold War World. The DISAM Journal, 1993, p. 83.

57 UNITED STATES. Address by the President of the United States of America William J. Clinton to the 48th of the United Nations General Assembly. Press Release USUN 140 - (93). 1993, p. 16.

58 Ver THIRD COMMITTEE. General Assembly. Report of the Chairman of the Working Group of the Third Committee. A/C.3/48/L.85. 1993.

59 Conforme documento localizado nos arquivos do Ministério das Relações Exteriores, em Brasília, a intenção inicial do presidente do Terceiro Comitê era apontar a embaixadora das Bahamas para a chefia do GT, mas as delegações do Movimento Não Alinhado, destacadamente Cuba e China, pressionaram contrariamente, e, assim, Ayala Lasso terminou sendo o indicado, o que foi do agrado tanto do Movimento Não Alinhado quanto do grupo ocidental, especialmente dos EUA, com os quais Ayala Lasso mantinha bom trânsito diplomático.

60 Apesar de não haver registros dos debates do GT, há relatoria do Terceiro Comitê. Os europeus ocidentais a se manifestarem em apoio àquela visão do ACNUDH foram: Bélgica, Noruega, Áustria, Suécia, Finlândia, Malta, Suíça e França. Ver: THIRD COMMITTEE. General Assembly. Summary Record of the 36th Meeting. A/C.3/48/SR.36, 1993. Idem. Summary Record of the 40th Meeting. A/C.3/48/SR.40, 1993. Idem. Summary Record of the 41st Meeting. A/C.3/48/SR.41, 1993. Idem. Summary Record of the 44th Meeting. A/C.3/48/ SR.44, 1993. Idem. Summary Record of the 46th Meeting. A/C.3/48/SR.46, 1993. Idem. Summary Record of the 47th Meeting. A/C.3/48/SR.47, 1993. Idem. Summary Record of the 48th Meeting. A/C.3/48/SR.48, 1993. Idem. Summary Record of the 51st Meeting. A/C.3/48/ SR.51, 1993.

61 THIRD COMMITTEE. General Assembly. Summary Record of the 43rd Meeting. A/C.3/48/SR.43, 1993. Idem. Summary Record of the 46th Meeting. A/C.3/48/SR.46, 1993. Idem. Summary Record of the 51st Meeting. A/C.3/48/SR.51, 1993.

62 Pronunciaram-se nessa direção no Terceiro Comitê os seguintes latino-americanos: Nicarágua, Chile, Panamá, México, Brasil, Venezuela, Guatemala, Costa Rica, Colômbia e Peru. Ver THIRD COMMITTEE. General Assembly. Summary Record of the 36th Meeting. A/C.3/48/SR.36, 1993. Idem. Summary Record of the 41st Meeting. A/C.3/48/SR.41, 1993. Idem. Summary Record of the 42nd Meeting. A/C.3/48/SR.42, 1993. Idem. Summary Record of the 43rd Meeting. A/C.3/48/SR.43, 1993. Idem. Summary Record of the 45th Meeting. A/C.3/48/SR.45, 1993. Idem. Summary Record of the 46th Meeting. A/C.3/48/SR.46, 1993. Idem. Summary Record of the 47th Meeting. A/C.3/48/SR.47, 1993. Entre os africanos: Marrocos, Gana, Nigéria, Lesoto; Camarões, Egito, Quênia, Tunísia e Gâmbia. Ver THIRD COMMITTEE. General Assembly. Summary Record of the 41st Meeting. A/C.3/48/SR.41, 
1993. Idem. Summary Record of the 44th Meeting. A/C.3/48/SR.44, 1993. Idem. Summary Record of the 45th Meeting. A/C.3/48/SR.45, 1993. Idem. Summary Record of the 46th Meeting. A/C.3/48/SR.46, 1993. Idem. Summary Record of the 49th Meeting. A/C.3/48/SR.49, 1993. Idem. Summary Record of the 51st Meeting. A/C.3/48/SR.51, 1993.

63 Fizeram pronunciamentos no Terceiro Comitê nessa linha: Paquistão, Líbia, Malásia, Indonésia, Nepal, Cuba e Vietnã. Ver THIRD COMMITTEE. General Assembly. Summary Record of the 43rd Meeting. A/C.3/48/SR.43, 1993. Idem. Summary Record of the 44th Meeting. A/C.3/48/SR.44, 1993. Idem. Summary Record of the 47th Meeting. A/C.3/48/SR.47, 1993. Idem. Summary Record of the 49th Meeting. A/C.3/48/SR.49, 1993. Entre os asiáticos, Japão e Coreia do Sul se aproximavam da posição ocidental, enquanto a Índia, do posicionamento latino-americano.

64 Pronunciaram-se Eslovênia, Bulgária, República Tcheca, Polônia, Lituânia, Croácia, Romênia, Hungria e Estônia. Ver THIRD COMMITTEE. General Assembly. Summary Record of the 38th Meeting. A/C.3/48/SR.38, 1993. Idem. Summary Record of the 43rd Meeting. A/C.3/48/SR.43, 1993. Idem. Summary Record of the 44th Meeting. A/C.3/48/SR.44, 1993. Idem. Summary Record of the 46th Meeting. A/C.3/48/SR.46, 1993. Idem. Summary Record of the 47th Meeting. A/C.3/48/SR.47, 1993. Idem. Summary Record of the 48th Meeting. A/C.3/48/SR.48, 1993. Idem. Summary Record of the 39th Meeting. A/C.3/48/SR.39, 1993.

65 THIRD COMMITTEE. General Assembly. United States of America: draft resolution Establishment of a United Nations High Commissioner for Human Rights. A/C.3/48/L.59. 1993.

66 CLAPHAM, Andrew. Creating the High Commissioner for Human Rights...Op. cit., p. 562.

67 Ibid., p. 562-563.

68 Vale mencionar que um dia após a apresentação da proposta dos EUA, um grupo de delegações apresentou um esboço de resolução, sob o titulo Strengthening of United Nations action in the human rights field through the promotion of international cooperation and the importance of non-selectivity, impartiality and objectivity, sem nenhuma menção ao ACNUDH. Esse grupo foi formado por Bangladesh, China, Coreia do Norte, Cuba, Gabão, Gana, Indonésia, Irã, Iraque, Laos, Malásia, México, Namíbia, Nigéria, Paquistão, Peru, Sudão, Tanzânia, Vietnã, Zâmbia e Zimbábue. Ver THIRD COMMITTEE. General Assembly. Strengthening of United Nations action in the human rights field through the promotion of international cooperation and the importance of non-selectivity, impartiality and objectivity. A/C.3/48/L.45. 1993.

69 O Brasil vocalizou esse descontentamento com a atitude dos EUA dentro do GT. Segundo a delegação brasileira, as datas limites da Assembleia Geral podiam ser modificadas e o GT não necessariamente precisaria terminar a discussão ao fim de 1993, mas poderia continuar os debates antes da Assembleia de 1994, no chamado período intersessional. Com isso, o Brasil marcou a posição da maioria dos países em desenvolvimento: apoio ao ACNUDH e apoio à construção de um esboço liderado por Ayala Lasso (BRASIL, 1993a). Ver BRASIL. Ministério das Relações Exteriores. XLVIII AGNU - Relatório III Comissão, p. 69-90. 1993.

70 THIRD COMMITTEE. General Assembly. Malaysia: proposed amendments to draft resolution A/C.3/48/L.59 - Establishment of a United Nations High Commissioner for Human Rights. A/C.3/48/L.79, 1993.

71 No mesmo dia, o representante cubano afirmou no Terceiro Comitê, segundo relatoria presente na documentação oficial da ONU: "Cuba had supported the decision to establish 
a working group of the Third Committee to follow up on recommendations concerning the establishment of a High Commissioner for Human Rights. His delegation was surprised by unilateral attempts to derail that process; such attempts to hasten or impose any decision that was not the necessary and logical result of that process would only introduce new sources of friction and create fresh obstacles to the promotion and protection of human rights." THIRD COMMITTEE. General Assembly. Summary Record of the 49th Meeting. A/C.3/48/SR.49, 1993, p. 9.

72 THIRD COMMITTEE. General Assembly. Report of the Third Committee (Part V). A/48/632/Add.4, 1993

73 CLAPHAM, Andrew. Creating the High Commissioner for Human Rights...Op. cit., p. 564.

74 A delegação de Gana, por exemplo, afirmou no plenário do Terceiro Comitê: "Any temptation to invest the Office with the authority to impose sanctions or establish conditions for development assistance should be resisted." THIRD COMMITTEE. General Assembly. Summary Record of the 45th Meeting. A/C.3/48/SR.45, 1993, p. 11.

75 Ver UNITED NATIONS. General Assembly. Declaration on the Right to Development. A/RES/41/128, 1986.

76 THIRD COMMITTEE. General Assembly. Report of the Chairman...Op. cit.

77 Idem. Summary Record of the 56th Meeting. A/C.3/48/SR.56, 1993.

78 A versão acabada da resolução que contém o mandato do ACNUDH aprovado pela Assembleia Geral foi publicada oficialmente em 7 de janeiro de 1994, sob o registro 48/141. Ver UNITED NATIONS. General Assembly. High Commissioner for Human Rights. A/ RES/48/141. 1994.

Recebido em 17/05/2017

Aprovado em 03/11/2017 